\title{
DIE SA WEERMAG EN BEWARING
}

\begin{abstract}
Watch an old building with anxious care, guard it as best you may, and at any cost, from any influence of dilapidation.

Count it's stones as you would the jewels in a crown. Set watchers about, as if at the gates of a besieged city. Bind it together with iron when it loosens, stay it with timber when it declines and do this tenderly and reverently and continually and a generation will be born and pass away beneath its shadow - John Ruskin.
\end{abstract}

In 1972 het Staatspresident J.J. Fouché in 'n voorwoord tot J.J Oberholster se boek oor Historiese Monumente van Suid-Afrika die volgende geskrywe:

'Die Republiek staan in die teken van vooruitgang en dit is vanselfsprekend dat die oog strak op die toekoms gerig is. In die proses moet ou geboue vir nuwes plek maak, kry historiese terreine gebruikswaarde en ons oudhede handelswaarde. Dit is 'n natuurlike ontwikkeling, maar dit hou gevare in. Die materiële nalatenskap van 'n beskaafde volk versinnebeeld sy geestelike groei en inhoud. Die onoordeelkundige en bewustelike vernietiging van ons tasbare en sigbare kultuurerfenisse is dus gelyk aan die uitwissing van ons historiese tradisie teen die agtergrond waarvan ons alleen die hede kan begryp en die toekoms verantwoordelik kan beplan.'

Die SA Weermag - en ook ander weermagte word gewoonlik met destruksie geassosieer. Die bydrae van die SA Weermag tot die behoud van die land se kultuurerfenis word dan gewoonlik eensydig uit die oog verloor.

Die SA Weermag het ' $n$ ryke tradisie. Tradisies waarvan sommige bykans net so oud as die volksplanting self is. Hierdie tradisies word jaloers bewaar want dit is die fondamente waarop verder gebou kan word. Hierdie tradisies wat verband hou met parades, formele etes, uniforms, gedenkdae en so meer, is nie al kultuur wat die Weermag jaloers in stand hou nie.
Uit die aard van sy werksaamhede beskik die Weermag oor groot stukke grond. Die Flora en Fauna wat op hierdie grond voorkom, word ten volle teen kwaadwillige beskadiging en uitroeiing beskerm. Ook argeologiese terreine, soos dié by Vhembe, word volwaardig beskerm. Die lys eindig nie hiermee nie. Selfs ou historiese geboue geniet die aandag van die SA Weermag; trouens, dit is opvallend dat die Weermag gewoonlik in die oudste geboue in 'n stad of dorp gehuisves is. Sodanige geboue word met trots beset en in stand gehou. Dit is tewens ook die beste metode van bewaring. Mense gee aan ' $n$ gebou lewe. As 'n gebou nie bewoon word nie verander dit in 'n murasie en word die prooi van stootskrapers.

Met hierdie bewaringspoging is geen fout te vind nie, want die SA Weermag is tog immers daar om sorg te dra dat die kultuurerfenis van SuidAfrika nie in vreemde hande val nie. Die trots op nasionale prestasies, die drang om die erfenis te bewaar spreek van piëteit vir die verlede sowel as patriotisme van die hede - kenmerke so eie aan die SA Weermag.

Sommige van hierdie geboue wat deur die Weermag gebruik word, is reeds as Nasionale Gedenkwaardighede deur die Raad vir Nasionale Gedenkwaardighede geproklameer. Sommige is in die proses van proklamering. Ander plekke waar dit onprakties of onmoontlik is om proklamering tot ' $n$ gedenkwaardigheid te oorweeg, word met 'n bronsplaat gemerk.

Die Redaksie beoog om in die eersvolgende uitgawes van Militaria kriptiese geskiedenisse oor sodanige 'ou' geboue wat deur die SA Weermag gebruik word, te publiseer. Ten einde die Redaksie in staat te stel om reg aan geboue buite Pretoria/Voortrekkerhoogte te laat geskied word eenhede aangemoedig om die geboue wat hulle gebruik se geskiedenis plus foto's aan Militaria te verskaf

\section{ARTILLERIERY 1 - 15, VERDEDIGINGSHOOFKWARTIER, PRETORIA}

Naas Kerkplein se wesfasade, is Artilleriery Pretoria se belangrikste historiese straatbeeld. Nie alleen dateer hierdie huise uit dieselfde tydperk 
nie, maar hulle is ook in dieselfde styl ontwerp. In sy 'Memorie van Toelichting' (1894) het Klaas van Ryse verklaar dat dit vir offisiere tradisioneel was om by die militêre kamp te woon en as gevolg hiervan is Artilleriery $1-15$ teen die middel van 1897 voltooi.

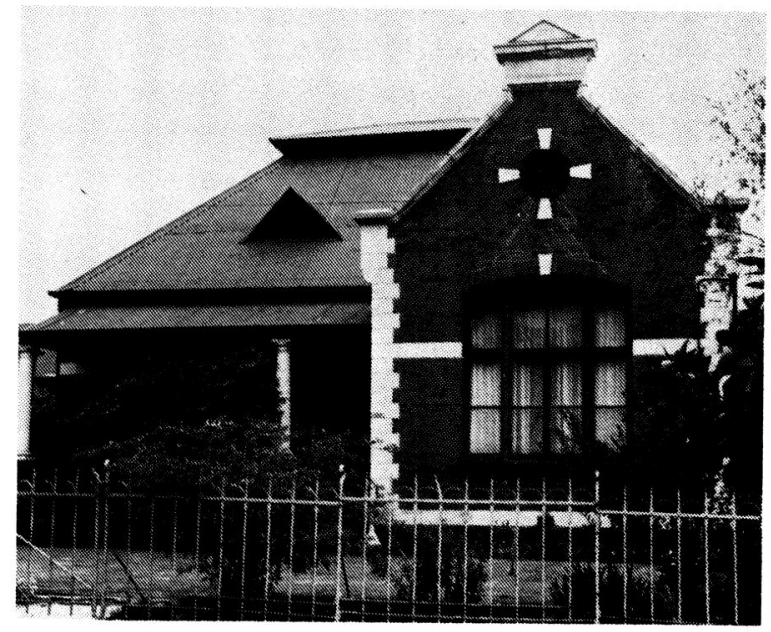

Hulle vorm dus 'n unieke en geordende argitektoniese geheel wat vir geen ander historiese straatbeeld in Suid-Afrika hoef terug te staan nie. Al 15 die huise in Artilleriery is in 1975 tot Nasionale Gedenkwaardighede verklaar

\section{OU STAATSARTILLERIESTALLE, VERDEDIGINGSHOOFKWARTIER, PRETORIA}

Die ou Staatsartilleriestalle laat mens vandag besef watter belangrike rol die perd destyds in die lewe van veral die Boer gespeel het, nie alleen in die alledaagse lewe nie maar ook in militêre verband.

Op die terrein van 5 Basiskrygbehoeftesdepot (5 $B K D$ ), net wes van Verdedigingshoofkwartier, staan die agt voormalige Staatsartilleriestalle wat tans as pakhuise en stoorkamers gebruik word. Die geboue is in 1896 voltooi.

Hoewel die interieur van sommige van die geboue reeds verander is, is daar nog baie oorspronklike items wat die aanslag van die tyd en onsimpatieke beplanners weerstaan het: eikehoutkeistene, kolonne, dreineringskanale en stalteëls van gietyster, hyshokke waarmee voer na die voersolder opgetrek is, hysluike, staldeure en vele ander voorwerpe wat nog aan die oorspronklike bestemming van die geboue herinner. Vandag is hierdie anachronismes van on- skatbare waarde vir die student van die geskiedenis van ons kultuur en boukuns.

Die eksterieur van die geboue het oorspronklik uit rooibaksteen en sandsteen bestaan maar sommige stalle is ongelukkig reeds afgepleister. Hierdeur is die karakter en voorkoms van die geboue drasties en ingrypend verander.

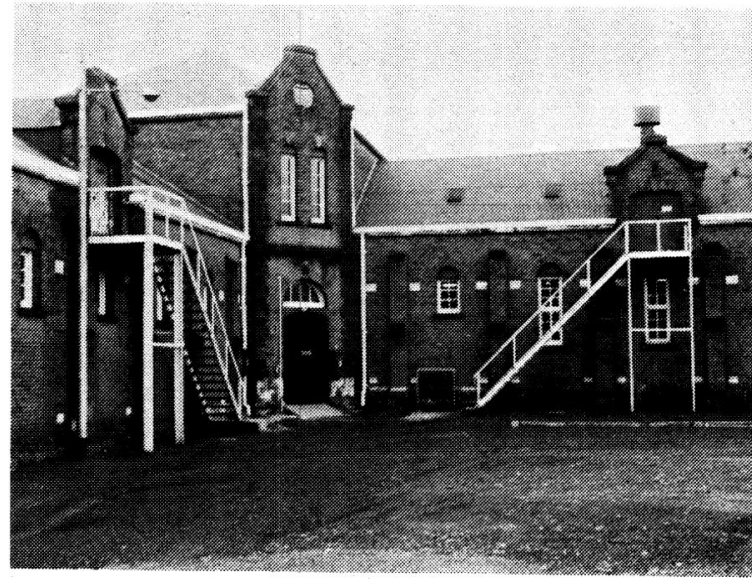

Benewens die stalle se militêr-historiese waarde, maak hulle ook 'n argitektoniese geheel uit wat as gebougroep vir die nageslag bewaar word. Om dit te verseker is die stallekompleks in 1977 tot nasionale gedenkwaardigheid verklaar.

\section{SA LEËRKOLLEGEHOOFGEBOU, VOORTREKKERHOOGTE, PRETORIA}

Die SA Leërkollege is die moederinrigting van byna alle vertakkinge van militêre opleiding in Suid-Afrika. Die hoofgebou, waaruit 'n rustige akademiese atmosfeer straal, is dus onlosmaaklik aan die huidige militêre tradisie verbonde en is ' $n$ waardige hoofkwartier vir die Kollege.

Kort na die Britse besetting van Pretoria op 5 Junie 1900, is 'n soldatekantien op die ou markplein (nou Strijdomplein) opgerig. Die kantien het binne twee jaar ' $n$ wins van $£ 20000$ getoon en lord Kitchener het besluit om met dié wins 'n ontspanningsentrum vir sy soldate op Roberts Heights op te rig. Die hoeksteen van hierdie eerste permanente gebou wat as die South African Garrison Institute bekend gestaan het, is op 12 Junie 1902 deur Kitchener self gelê.

Die eenvoudige, maar statige, langwerpige gebou van twee verdiepings is in die sogenaamde blokhuisstyl ontwerp en van rooi sandsteen gebou. $\mathrm{Na}$ afloop van die oorlog is die gebou aan die Departement van Verdediging 
oorgedra en in 1920 het die Militêre Skool daar ontstaan toe besluit is om die verstrooide militêre opleidingstakke op Roberts Heights te sentraliseer. Op 1 Julie 1924 is Kollege-status aan die inrigting toegeken. Die stigting van die SA Lugmagkollege in 1928 het daartoe gelei dat die SA Militêre Kollege se naam op 1 Maart 1968 na dié van SA Leërkollege verander is.

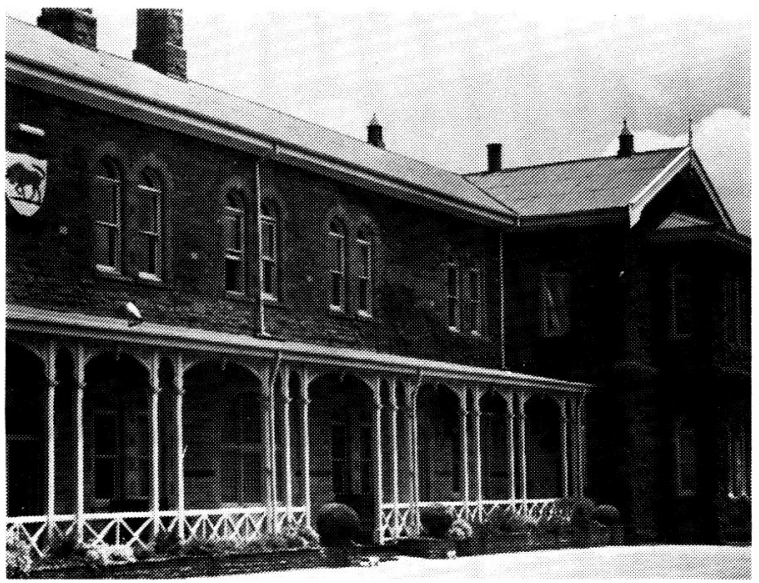

Die SA Leërkollege is in 1979 tot Nasionale Gedenkwaardigheid verklaar.

\section{DIE SUID-AFRIKAANSE LUGMAGOFFISIERSKLUBGEBOU, VOORTREKKERHOOGTE, PRETORIA}

In Junie 1902 het genl (later Sir) Neville Lyttelton vir Kitchener as opperbevelhebber van die Britse Magte in Suid-Afrika opgevolg. Kitchener se huis (Melrose House) kon nie as vredestydse akkommodasie vir ' $n$ bevelvoerende generaal gebruik word nie en is 'n stuk grond tussen die Roberts Heights kantonnement en die plaas Groenkloof toegestaan vir die bou van General's House. Herbert Baker was die argitek en die huis is teen die einde van 1903 voltooi. Lyttelton en sy opvolgers het gevolglik die woning wat ook as Headquarters House bekend gestaan het be- woon en waarskynlik ook as hoofkwartier gebruik.

Vir die tydperk 1912 - 1920 is slegs bekend dat A.G.G. Mylrea die huis, buitegeboue en grond in Februarie 1914 as melkery gebruik het. Vroeg in 1921 is dit deur nonne as 'n skool of crèche gebruik.

Op 1 Februarie 1920 is die Suid-Afrikaanse Lugmag as eerste Statebondslugmag gestig met Sir Pierre van Ryneveld aan die hoof. In Maart 1921 is Headquarters House deur die nonne ontruim en in Julie 1921 het die Lugmag die gebou as Hoofkwartier gebruik en is dit as sodanig gebruik tot in 1932. Daarna het dit 'n klub vir garnisoenoffisiere geword en later net vir Lugmagoffisiere.

Die oorspronklike gedeelte van die gebou wat vandag as die SA Lugmagoffisiersklubgebou bekend staan, asook die tuin en die mooi hek wat toegang tot die terrein verleen, is in 1981 tot nasionale gedenkwaardigheid verklaar.

*Die gegewens mbt die voorafgaande vier Nasionale Gedenkwaardighede is verkry van die Transvaalse Streekskomitee van die Raad van Nasionale Gedenkwaardighede.

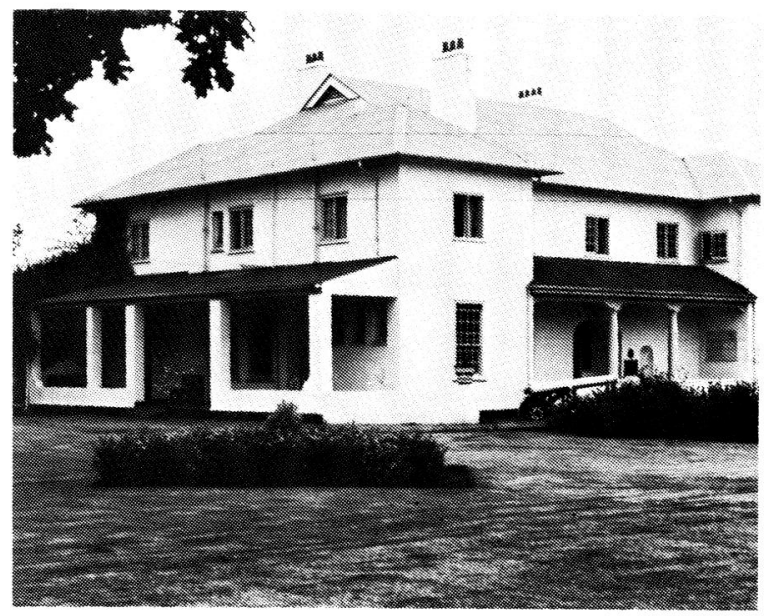

